\title{
Phytochemical Screening and In-vitro Antioxidant Profiling of Solvent Fractions of Canna edulis Ker Gawler
}

\author{
Tanmayee Mishra, Abhaya Prasad Das and Arnab Sen* \\ Molecular Cytogenetics Laboratory, Department of Botany, University of North Bengal, Siliguri-734013, West Bengal, India. \\ E-mail:tanmayeemishra@yahoo.co.in; apdas.nbu@gmail.com; senarnab_nbu@hotmail.com
}

\section{ABSTRACT}

Introduction: Canna edulis Ker Gawler, grown in the sub Himalayan region containing starchy rhizome are used by the tribal people as food and herbal medicine. Methods: Investigations were done to find out 2,2-diphenyl-1-picryl hydrazyl (DPPH) radical scavenging activity, total flavonols and total proanthocyanidin contents, nitric oxide (NO) scavenging activity, hydroxyl radical scavenging activity of different solvent fractions of aquous extract of $C$. edulis rhizome. Among the cellular molecules, lipids containing unsaturated fatty acids with more than one double bond are particularly susceptible to action of free radicals. The resulting reaction, known as lipid peroxidation and anti lipid peroxidation activity has been performed using goat liver homogenate. Results: Six out of 29 fractions showed DPPH free radical inhibition above $75 \%$ and were used for further phytochemical screening. Diethyl ether : ethyl acetate (1:3) fraction showed the maximum inhibition percent. Highest amount of total flavonol and total proanthocyanidins were recorded in diethyl ether : ethyl acetate (1:3) fraction. Maximum NO scavenging activity and hydroxyl radical inhibition activity were observed in bioactive diethyl ether : ethyl acetate (1:1) fraction. Inhibition of lipid peroxides was maximum in ethyl acetate fraction. Data from thin layer chromatography (TLC) revealed the presence of phenolic compounds in all fractions, whereas flavonoid glycoside compounds were restricted in ethyl acetate and diethyl ether : ethyl acetate (1:3). Conclusions: Thus it can be concluded that the antiradical scavenging activity of Canna rhizome may be due to the presence of polyphenolic compouns like phenols, flavonoids, proanthocynidins etc.

Keywords: Anti-lipid peroxidation, Canna, column chromatography, DPPH, polar.

\section{INTRODUCTION}

Oxygen plays a vital role in the survival of life on earth. However, during it's utilization in various life processes, a tiny amount of oxygen gets reduced to different free radicals like hydrogen peroxide, superoxide, nitric oxide, hydroxyl radicals etc. ${ }^{[1,2]}$ All these reactive oxygen radicals are accountable for various health hazards to human life causing the development of degenerative diseases. ${ }^{[3]}$ Antioxidant molecules, on the other hand, can slow down or cease the activity of these harmful oxygen species by being oxidizing

*Address for correspondence:

Telephone: +91-353-36528172, Fax +91-353-2699001

E-mail: senarnab_nbu@hotmail.com

DOI: $10.5530 / a x .2012 .2 .5$ themselves. Plants often contain good amount of natural antioxidants. ${ }^{[4,5]}$ Different phytochemicals like phenols, flavonols, carotenoids, proanthocyanidins, vitamin $\mathrm{C}$ and $\mathrm{E}$ can be utilized to scavenge the excess free radicals from human body. ${ }^{[6]}$

Canna edulis Ker Gawler, is a medium sized perennial flowering plant found in the north eastern Himalayan regions of India. ${ }^{[7}$ The plants bear broad, flat, blackish green leaves with spectacular red flowers. Besides, it also tickles our test buds as it is known to be edible and mainly consumed by the Indian tribes like Lepchas, Bhutias and Nepalis. ${ }^{[8]}$ Different parts of the plants like rhizomes, leaves and seeds are used as medicines by the tribal communities of North eastern India. ${ }^{[9]}$ Amongst various plant parts the extracts of rhizomes are rich source of polyphenolic compounds like phenols and flavonoids, ${ }^{[10]}$ which in turn provide the evidences of antioxidative properties of the plant. 


\section{Antioxidant profiling of Canna edulis Ker Gawler}

The antioxidants like polyphenol and flavonoid contents of methanolic seed extracts of Canna indica were investigated to find out their inhibitory effects on oxidation of phosphatidylcholine (PC) liposomes and their aggregation, ${ }^{[11]}$ where as comparative analysis of total phenols, flavonoids and antioxidant activity by 2,2-diphenyl-1-picryl hydrazyl (DPPH) and trolox equivalent antioxidant capacity (TEAC) assay of methanolic extracts of red and yellow varieties of Canna indica was done to find out their role as potential source of natural antioxidants. ${ }^{[12]}$ Further the in vitro free radical scavenging activities of methanolic extract of aerial parts of Canna indica was investigated ${ }^{[13]}$ to indicate them as powerful antioxidants. Correlation of in vitro antioxidant properties and radical scavenging activity was analysed between the cold and hot aquous extracts of $C$. edulis rhizome. ${ }^{[10]}$ However, no information on the separation of phytochemicals in different solvent fractions i.e from less polar solvent (hexane) to highly polar solvent (water) have been done. Taking this into consideration, in the present study, total flavonol, total proanthocyanidins, nitric oxide scavenging activity, hydroxyl radical scavenging activity and anti lipid peroxidation activity of different fractions of rhizome extract of Canna edulis Ker Gawler found in the sub Himalayan West Bengal and Darjeeling hills have been taken up. Detection of compound of bioactive fractions through thin layer chromatography (TLC) has also been performed.

\section{MATERIALS AND METHODS}

\section{Chemicals Used}

DPPH (2,2-diphenyl-1-picryl hydrazyl), ferric chloride, vanillin, sulphanilamide and naphthylethylene diamine dihydrochloride were procured from HiMedia Laboratories Pvt. Ltd, Mumbai, India. Ethylenediamine tetra acetic acid (EDTA), methanol, potassium dihydrogen phosphate $\left(\mathrm{KH}_{2} \mathrm{PO}_{4}\right)$, di-hydrogen potassium phosphate $\left(\mathrm{K}_{2} \mathrm{HPO}_{4}\right)$, potassium hydroxide, sodium hydroxide, ascorbic acid, 2-deoxy-D-ribose, trichloroacetic acid (TCA), quercetin, hydrogen peroxide, butylated hydroxytoluene (BHT), aluminium chloride $\left(\mathrm{AlCl}_{3}\right)$, potassium chloride, ferrous sulphate, sodium acetate, sodium nitroprusside, butanol, ethanol, ethyl acetate, ammania, iodine reagent, glacial acetic acid and hydrochloric acid $(\mathrm{HCl})$ were purchased from Merck, Mumbai, India. Orthophosphoric acid, hexane, benzene, chloroform, diethyl ether, ethyl acetate, acetone etc. were procured from SD fine chem Limited, Mumbai, India. Thiobarbituric acid (TBA) was obtained from Loba Chemical, Mumbai, India. Polyethylene glycol was procured from Qualigens, Mumbai, India. Trizma base was procured from Sigma chemicals. All chemicals and solvents are of analytical grade.

\section{Animal material}

Goat liver, which was used for anti lipid peroxidation assay, was collected from slaughter house immediately after slay. Experiment was conducted within one hour after collection.

\section{Plant material}

C. edulis germplasm was collected from hilly regions of Darjeeling (Latitude $27.03^{\circ} \mathrm{N}$, Longitude $88.18^{\circ} \mathrm{E}$ ), West Bengal, India in the fall of 2008. The authentication of the plant material was done at the Taxonomy and Environmental Biology Laboratory, University of North Bengal. The material has been deposited in the "NBU Herbarium" against the accession no. 9588.

\section{Rhizome extracts}

Ten grams of rhizome of C. edulis were taken and washed properly and dried. These were then crushed in $40 \mathrm{ml}$ of double distilled water $\left(\mathrm{DDH}_{2} \mathrm{O}\right)$ using mechanical grinder to get the required concentration of 1:4 (biomass: $\mathrm{H}_{2} \mathrm{O}$, $\mathrm{w} / \mathrm{v})$. The extract was soxhleted exhaustively at boiling temperature for a period of 12 hours. The aquous extract thus obtained was evaporated at $45{ }^{\circ} \mathrm{C}$ to make a final volume of $3 \mathrm{ml}$. It was then subjected to Silica gel ( SD fine chem Limited, 200-300 mesh size) column chromatography. Different solvents (base on their polarity level) like hexane, benzene, chloroform, diethyl ether, ethyl acetate, acetone, methanol and water were eluted in the column to separate different phytochemicals in order of their affinity towards these solvents. The above series of less polar to highly polar solvents were passed through the silica column in various combinations like 25, 50, 75 and $100 \%$ to get different solvent fractions. The fractions were air dried and dissolved in $5 \mathrm{ml}$ of methanol and stored in amber glass bottle at $4{ }^{\circ} \mathrm{C}$ until further use.

\section{DPPH radical scavenging activity}

The free radical scavenging capacity of all the solvent fractions were determined using 2,2-diphenyl-1-picryl hydrazyl (DPPH) $\cdot{ }^{[14,15]} \mathrm{DPPH}$ solution $(0.006 \% \mathrm{w} / \mathrm{v})$ was prepared in $95 \%$ methanol. One thousand eight hundred $\mu \mathrm{l}$ of freshly prepared DPPH solution was added to $200 \mu \mathrm{l}$ of the fractions $(200 \mathrm{mg} / \mathrm{l})$, to make a final volume of $2 \mathrm{ml}$. Discoloration of these extracts was measured at $517 \mathrm{~nm}$ after incubation for $30 \mathrm{~min}$ in dark at room temperature with Themo UV1 spectrophotometer. In case of -ve control same ingredients have been used except $200 \mu$ l of methanol 
in place of extract. DPPH scavenging activity (\%) was measured using the following formula:

$$
\mathrm{I}=\frac{\mathrm{A}_{0}-\mathrm{A}_{1}}{\mathrm{~A}_{0}} \times 100
$$

where $A_{0}$ was the absorbance of the control and $A_{1}$ was the absorbance in the presence of the sample (different fractions of Canna), whereas 'I' stood for \%age inhibition of DPPH. The actual decrease in absorption induced by the test compounds was compared with the positive controls.

The fraction showing maximum antiradical responses was diluted to different concentrations $(100 \mu \mathrm{g}$ to $1000 \mu \mathrm{g})$ and their antiradical activities were observed. $\mathrm{IC}_{50}$ value was calculated from graphical presentation of concentration verses radical scavenging activity. ${ }^{[16]}$

\section{Determination of total flavonol content}

Total flavonol content was determined using aluminium chloride $\left(\mathrm{AlCl}_{3}\right)$ method with quercetin as a standard. ${ }^{[17]}$ The bioactive fractions ( $2 \mathrm{ml}$ each) were mixed with equal volume of $2 \% \mathrm{AlCl}_{3}$ (ethanolic solution) followed by the addition of $3 \mathrm{ml}$ of $\mathrm{CH}_{3} \mathrm{COONa}(50 \mathrm{gm} / \mathrm{l})$. The mixture was incubated at $20^{\circ} \mathrm{C}$ for 2.5 hours. The absorbance was measured at $440 \mathrm{~nm}$. The flavonol content was calculated from a quercetin standard curve. ${ }^{[17]}$

\section{Determination of total proanthocyanidins}

Total proanthocyanidins was determined according to Sun et al., 1998, ${ }^{[18]}$ using catechin as a standard. The reaction mixture contains $0.5 \mathrm{ml}$ of extract, $3 \mathrm{ml}$ of $4 \%$ methanolic solution of vanillin and $1.5 \mathrm{ml}$ of conc. $\mathrm{HCl}$ and incubated for $15 \mathrm{~min}$ at room temperature. The absorbance was measured at $500 \mathrm{~nm}$. The proanthocyanidin content was calculated from catechin standard curve.

\section{Inhibition of nitric oxide production}

Nitric oxide scavenging activity of bioactive fractions of Canna rhizome was determined as per standard protocol. ${ }^{[1,20]}$ Briefly, sodium nitroprusside solution (1 $\mathrm{ml}$ of $10 \mathrm{mM}$ ) was mixed with $1 \mathrm{ml}$ of different concentrations of bioactive fractions of C.edulis in $\mathrm{PO}_{4}$ buffer (pH-7.4). The mixture was incubated at $25^{\circ} \mathrm{C}$ for $150 \mathrm{~min}$. To $0.5 \mathrm{ml}$ of incubated solution, $1 \mathrm{ml}$ of Griess reagent $(1 \mathrm{ml}$ of $1 \%$ sulphanilamide, $0.5 \mathrm{ml}$ of $2 \%$ orthophosphoric acid and $1 \mathrm{ml}$ of $0.1 \%$ naphthyl ethylene diamine dihydrochloride) was added and the reaction mixture was incubated at $25^{\circ} \mathrm{C}$ for $30 \mathrm{~min}$. The absorbance of the pink chromophore formed by the diazotization of nitrite with sulphanilamide and subsequent coupling with naphthyl ethylene diamine dihydrochloride was measured at $540 \mathrm{~nm}$. Control sample was prepared containing the same volume without any extract. Nitric oxide scavenging activity (\%) was calculated using formula 1 , where 'I' stood for \%age inhibition of NO.

\section{Hydroxyl radical scavenging activity}

Hydroxyl radical scavenging activity was measured according to Kunchandy and Rao (1990) ${ }^{[21]}$ with some modifications, by studying the competition between test extract and deoxyribose for hydroxyl radical generated by Fenton's reaction. The reaction mixture containing $0.2 \mathrm{ml}$ of $20 \mathrm{mM}$ phosphate buffer (pH-7.4), $0.2 \mathrm{ml} \mathrm{FeCl}_{3}(10 \mathrm{mM}), 0.1 \mathrm{ml}$ ascorbic acid $(0.1 \mathrm{mM}), 0.1 \mathrm{ml}$ EDTA $(1 \mathrm{mM}), 0.1 \mathrm{ml} \mathrm{H}_{2} \mathrm{O}_{2}$ $(10 \mathrm{mM}), 0.2 \mathrm{ml}$ of 2-deoxy-D-ribose $(10 \mathrm{mM})$ and different concentration of bioactive fractions (1 $\mathrm{ml}$ each) was incubated at room temperature for $60 \mathrm{~min}$. To this $1 \mathrm{ml}$ each of $1 \%$ TBA and $2.8 \%$ TCA were added. The final mixture was kept in boiling water bath for 30 min to get pink chromophore. The damage imposed due to free radicals was determined colorimetrically by measuring the thiobarbituric acid reactive substances (TBARS) at $532 \mathrm{~nm}$. Control sample was prepared containing the same volume without any extract. Hydroxyl radical scavenging activity $(\%)$ was measured using formula 1 , where ' $\mathrm{I}$ ' stood for $\%$ age inhibition of $\mathrm{OH}^{-}$.

\section{Inhibition of lipid peroxidation activity}

Lipid peroxide inhibition activity was determined in vitro according Kumar et al., 2000. ${ }^{[22]}$ Freshly collected goat liver homogenate was used as the source of polyunsaturated fatty acids for determining the extent of hepatocyte protective activity. Goat liver (5\%) was homogenized with $40 \mathrm{mM}$ tris $\mathrm{HCl}$ buffer and centrifuged at $1000 \mathrm{Xg}$ for $10 \mathrm{~min}$ to get a clear supernatant. Reaction mixture containing $0.5 \mathrm{ml}$ supernatant, different concentrations of bioactive fractions ( $1 \mathrm{ml} \mathrm{each}$ ), $100 \mu \mathrm{l}$ of . $15 \mathrm{M} \mathrm{KCl}, 1 \mathrm{ml}$ of $15 \mathrm{mM}$ $\mathrm{FeSO}_{4}, 1 \mathrm{ml}$ of $6 \mathrm{mM}$ ascorbic acid was incubated at $37^{\circ} \mathrm{C}$ for $1 \mathrm{hr}$. TCA ( $1 \mathrm{ml} ; 10 \%)$ was added to the mixture and the samples were centrifuged at $4000 \mathrm{Xg}$ for $20 \mathrm{~min}$ at $4{ }^{\circ} \mathrm{C}$ to remove insoluble proteins. Supernatant was removed and $1 \mathrm{ml}$ of TBA $(0.8 \%)$ was added to this fraction followed by heating at $90{ }^{\circ} \mathrm{C}$ for $20 \mathrm{~min}$ in a water bath. A pink chromophore was produced after cooling which was extracted with organic solvent ( $2 \mathrm{ml}$ ice cold butanol) and absorbance was measured at $532 \mathrm{~nm}$. Control sample was prepared containing the same volume without any extract. Inhibition of lipid peroxidation activity (\%) was calculated from formula 1, where ' $I$ ' stood for \%age inhibition of lipid peroxide. 


\section{Antioxidant profiling of Canna edulis Ker Gawler}

Detection of compounds through thin layer chromatography (TLC)

The bioactive fractions of $C$. edulis rhizome extract were analyzed through thin layer chromatography (TLC) using the method of Wagner and Bladt, 1996. ${ }^{[23]}$ About $10 \mu \mathrm{l}$ of extract $(2 \mathrm{mg} / \mathrm{ml})$ of all the bioactive fractions were loaded on TLC plates (Merck, India $10 \times 10 \mathrm{~cm}^{2}$ ). The plate was air dried and developed in Hexane: Diethyl ether (2:3) for $30 \mathrm{~min}$. The plate was dried in a hot oven (at $80^{\circ} \mathrm{C}$ for $10 \mathrm{~min}$ ) and detected under UV light (365 nm) and ammonia vapor. For spraying iodine solution, Natural Product/Polyethylene Glycol reagent (5\% NP/PEG in ethanolic solution), ferric chloride ( $1 \%$ solution in $50 \%$ aquous methanol) were used in the experiment.

All the tests were performed in triplets.

\section{Statistical Analysis}

Results are expressed as mean \pm S.E.M. of triplets. The groups were compared by two-way ANOVA using Graph Pad Prism, Version 5.0 (Graph Pad Software, San Diego, CA, USA). P-values $<0.001$ were considered significant.

\section{RESULTS}

\section{Identification of bioactive fraction}

In the present study, 29 solvent fractions were generated. Out of which 6 fractions showed inhibition above $75 \%$. Rest of the fractions showed inhibition less than 25\%, except one fraction [ethyl acetate: acetone (3:1)] which showed activity little over 50\% (figure 1). These six fractions are chloroform: diethyl ether (1:3) [Fr-A], diethyl ether [Fr-B], diethyl ether : ethyl acetate (3:1) [Fr-C], diethyl ether : ethyl acetate (1:1) [Fr-D], diethyl ether : ethyl acetate (1:3) [Fr-E], ethyl acetate [Fr-F] and identified as bioactive fractions of C. edulis rhizome. Interestingly these fractions are moderately polar and nonpolar. Six fractions which showed scavenging activity more than $75 \%$ were used for further phytochemical screening.

Fr-E [Diethyl ether: ethyl acetate (1:3)] showed the maximum inhibition percent $(93.08 \%$ ) for DPPH scavenging activity. The above fraction was diluted to different concentration $(100 \mu \mathrm{g}$ to1000 $\mu \mathrm{g})$ and subjected to DPPH assay. The most bioactive fraction showed a concentration dependent DPPH antiradical activity with $\mathrm{IC}_{50}$ of $658 \mu \mathrm{g} / \mathrm{ml}$ fresh weight basis.
Extractive yield of the bioactive fractions

Yield of these bioactive fractions were in the range of $5 \mathrm{mg} / \mathrm{ml}$ to $12 \mathrm{mg} / \mathrm{ml}$. These fractions were diluted to $1 \mathrm{mg} / \mathrm{ml}$ for further use.

Total flavonol and proanthocyanidin contents

The determination of total flavonol contents of the above six fractions showed flavonols ranging from $37.12 \mathrm{mg} / \mathrm{ml}$ to $9.92 \mathrm{mg} / \mathrm{ml}$ quercetin equivalent per $100 \mathrm{mg}$ rhizome extract [figure-2(a)]. As of DPPH antiradical activity, Fr-E also showed highest flavonol contents $(37.12 \mathrm{mg} / \mathrm{ml}$ quercetin equivalent per $100 \mathrm{mg}$ rhizome extract) followed by Fr-F $(25.12 \mathrm{mg} / \mathrm{ml}$ quercetin equivalent per $100 \mathrm{mg}$ rhizome extract). We found that total flavonol was found to be decreased with decrease in concentration.

We also studied total proanthocyanidin contents of above six fractions of Canna rhizome extract. [figure-2(b)]. Similar to flavonol contents, Fr-E had highest total proanthocyanidins (i.e. $0.012 \mathrm{mg} /$ catechin $/ \mathrm{g}$ dry weight) among all the bioactive fractions. Total proanthocyanides content showed a dose dependent increase with increase in concentration. Fr-F and Fr-A were recorded to contain least amount of total proanthocyanides $(0.0005 \mathrm{mg} /$ catechin $/ \mathrm{g}$ dry weight $)$ at $0.25 \mathrm{mg} / \mathrm{ml}$.

\section{Free radical inhibition activities}

In the present study, we observe the bioactive fractions of Canna rhizome inhibit the generation of $\mathrm{NO}$ radicals. Figure3(a) indicates that Canna rhizome has nitric oxide scavenging activity. Maximum scavenging activity observed in bioactive Fr-D was $78.41 \%$ at a concentration of $1 \mathrm{mg} / \mathrm{ml}$. Here we found that NO scavenging activity decreased with decrease in concentration.

Hydrogen peroxide reacts with ferrous salt to form hydroxyl radical via Fenton's reaction. ${ }^{[2]}$ The hydroxyl radical $\left(\mathrm{OH}^{-}\right)$thus produced may attack the sugar of DNA base causing sugar fragmentation, base loss and DNA strand breakage. ${ }^{[25]}$ In the present study, this hydroxyl radical scavenging activity was shown by all the six bioactive factions [figure-3(b)]. This radical scavenging activity showed a dose dependent increase with increase in concentration. The highest inhibition percent was observed in Fr-D (i.e. 39.04\% at a concentration of $1 \mathrm{mg} / \mathrm{ml}$ ).

Free radicals induce lipid peroxidation in polyunsaturated lipid rich area like brain and liver. ${ }^{[2]}$ We analysed that different Canna rhizome fractions showed protection against damage due to lipid peroxides [figure-3(c)]). Maximum inhibition 


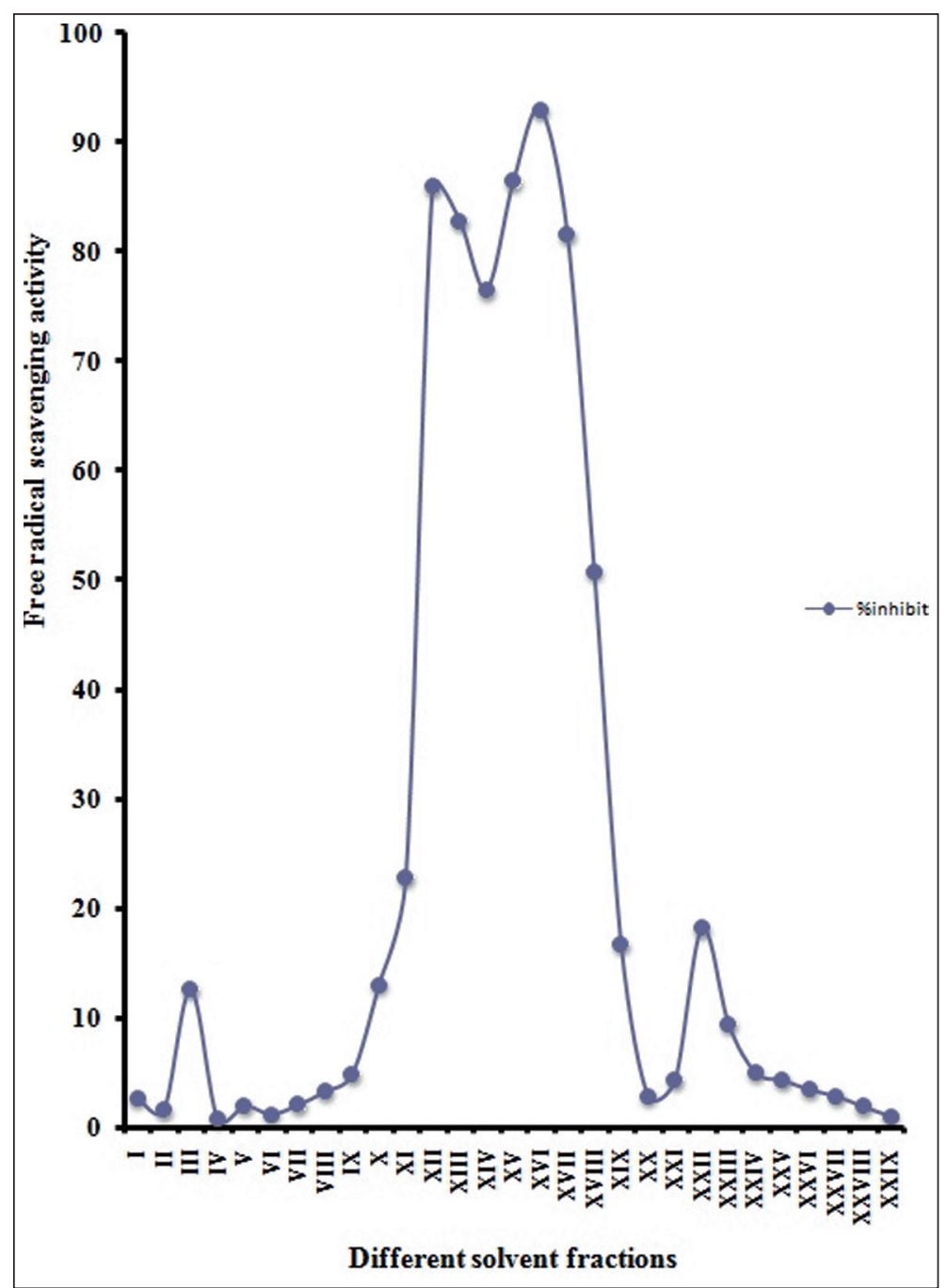

Figure 1: DPPH radical scavenging activities (\%) of different solvent fractions of C. edulis : I- Hexane, II- Hexane : Benzene (3:1), III-Hexane : Benzene (1:1), IV- Hexane :Benzene (1:3), V- Benzene, VI- Benzene :Chloroform (3:1), VII- Benzene : Chloroform (1:1), VIII- Benzene : Chloroform (1:3), IX- Chloroform, X- Chloroform : Diethyl ether (3:1), XI- Chloroform : Diethyl ether (1:1), XII- Chloroform : Diethyl ether (1:3), XII- Diethyl ether, XIV- Diethyl ether : Ethyl acetate (3:1), XV- Diethyl ether : Ethyl acetate (1:1), XVI- Diethyl ether : Ethyl acetate (1:3), XVII- Ethyl acetate, XVII- Ethyl acetate : Acetone (3:1), XIX- Ethyl acetate : Acetone (1:1), XX- Ethyl acetate : Acetone (1:3), XXI- Acetone, XXII- Acetone : Methanol (3:1), XXIIIAcetone : Methanol (1:1), XXIV- Acetone : Methanol (3:1), XXV- Methanol, XXVI- Methanol : Water (3:1), XXVII- Methanol : Water (1:1), XXVIIIMethanol : Water (1:3), XXIX- Water.

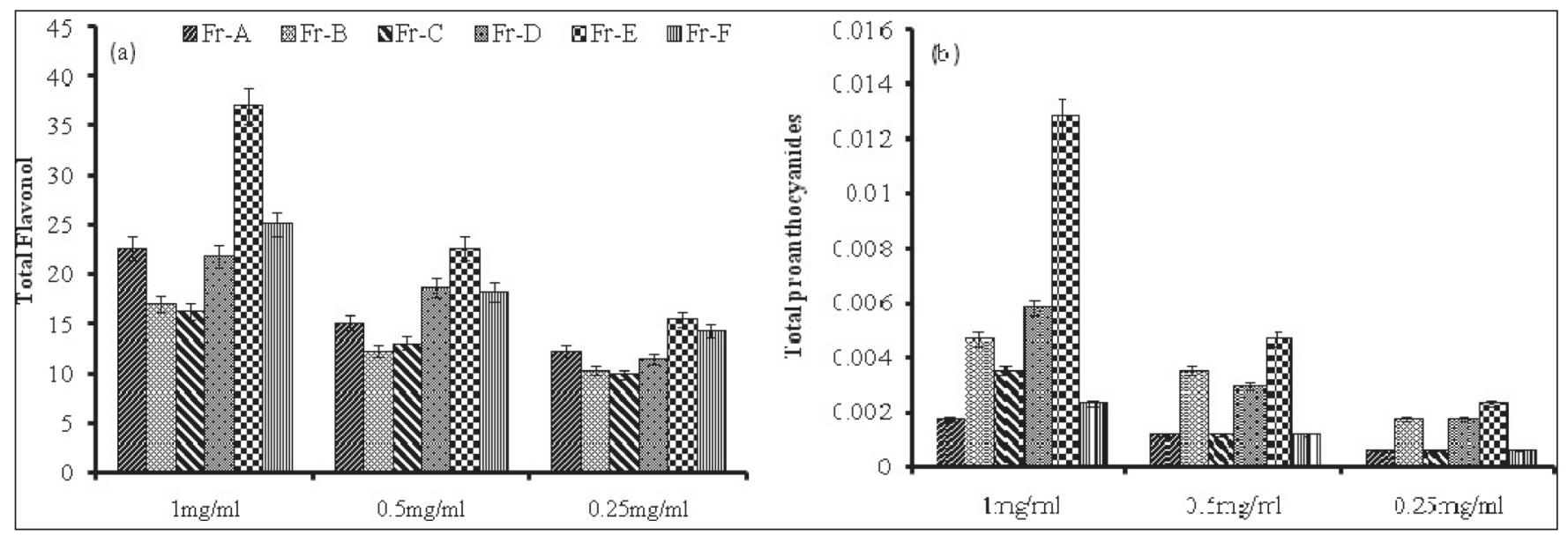

Figure 2: (a) Total flavonols of bioactive solvent fractions of Canna (b) Total proanthocyanidins of bioactive solvent fractions of Canna. Here $X$ and $\mathrm{Y}$ axes represent Conc. of solvent fractions and Inhibition percent respectively. 


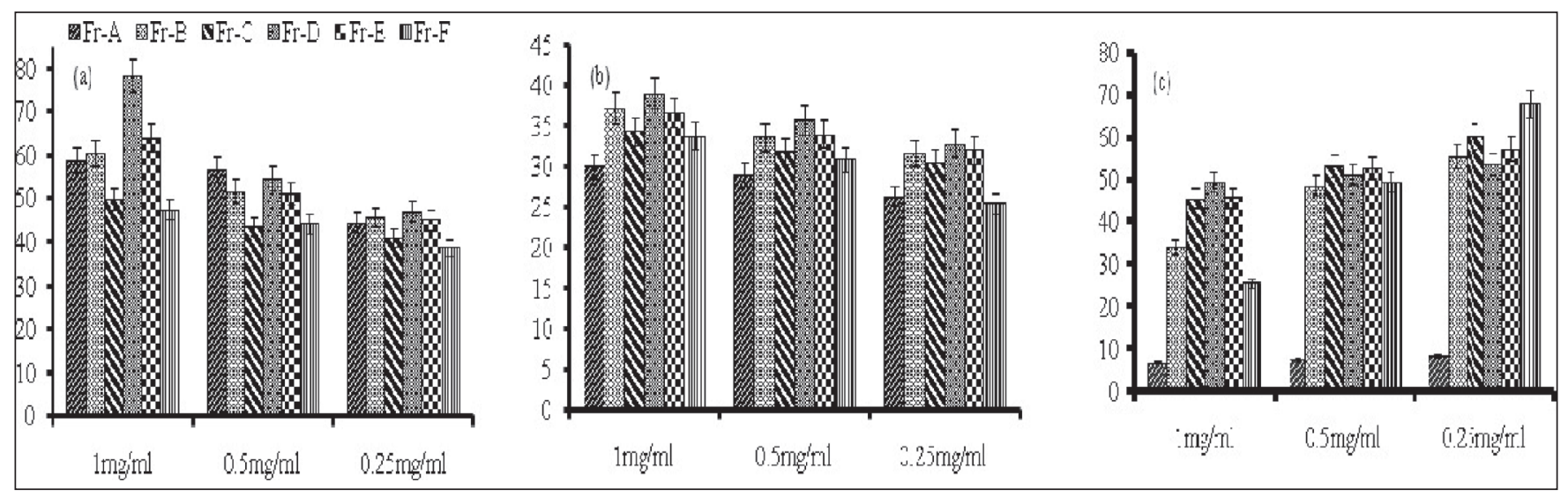

Figure 3: (a) Nitric oxide scavenging activity of bioactive solvent fractions of Canna (b) Hydroxyl radical scavenging activity of bioactive solvent fractions of Canna (c) Lipid peroxidase activity. Here $\mathrm{X}$ and $\mathrm{Y}$ axes represent Conc. of solvent fractions and Inhibition percent respectively.

Table 1: List of some qualitative characters of spots visualized on TLC plate after chromatographic development with different reagents. Within parenthesis is the band intensity.

\begin{tabular}{|c|c|c|c|c|}
\hline Sol frac ${ }^{a}$ Reagents & $\begin{array}{c}\text { Ammonia } \\
\left(\mathrm{NH}_{3}\right)\end{array}$ & lodine $\left(I_{2}\right)$ & $\begin{array}{l}\text { Ferric chloride } \\
\qquad\left(\mathrm{FeCl}_{3}\right)\end{array}$ & NP/PEG ${ }^{b}$ \\
\hline Fr-A & Violet $(+)$ & Brown (+) & Yellow $(++)$ & - \\
\hline Fr-B & Violet $(+++)$ & Brown $(++)$ & Yellow $(++)$ & - \\
\hline $\mathrm{Fr}-\mathrm{C}$ & Violet (+) & - & Yellow (+) & - \\
\hline Fr-D & Violet $(+++)$ & Brown $(++)$ & Yellow $(++)$ & Orange (+) \\
\hline Fr-E & Violet $(+++)$ & Brown $(++)$ & Yellow $(+++)$ & Orange $(+++)$ \\
\hline $\mathrm{Fr}-\mathrm{F}$ & Violet $(+)$ & Brown $(++)$ & Yellow $(++)$ & Orange $(+++)$ \\
\hline $\begin{array}{l}\text { Probable } \\
\text { phytochemical group }\end{array}$ & $\begin{array}{l}\text { Polyphenolic } \\
\text { compounds }\end{array}$ & $\begin{array}{l}\text { Unsaturated } \\
\text { aromatic compounds }\end{array}$ & $\begin{array}{l}\text { Phenolic } \\
\text { compounds }\end{array}$ & $\begin{array}{l}\text { Flavonoid glycoside i.e. triterpene } \\
\text { glycoside compound }\end{array}$ \\
\hline
\end{tabular}

${ }^{\mathrm{a}}$ Sol frac- Solvent fraction ${ }^{\mathrm{b}} \mathrm{NP} / \mathrm{PEG}$ - Natural Product/ Polyethylene glycol

was recorded in Fr-F (67.89\%) and lowest in Fr-A (8.27\%). Here we observed hepatocyte protective activity increases with decrease in concentration.

\section{Compound detection through TLC}

Highly fluorescent bands were viewed in three bioactive fractions like Fr-B, Fr-D and Fr-E under UV light (365 $\mathrm{nm})$. The compounds were separarated in the TLC plate and viewed as described in table I.

\section{DISCUSSION}

Total flavonol and proanthocyanidin contents

Canna edulis rhizome extracts have been considered to be a source of natural antioxidants as it contains higher amount polyphenolic compounds. ${ }^{[27]}$ In this study, we found, elevated amount of total flavonols and proanthocyanidins in bioactive Fr-E. The release of high extent of flavanols may be due to the affinity of free hydroxyl group of flavonoid compounds towards ethyl acetate and diethyl ether fractions while, the nucleophilic character of proanthocyanidins, which have more attraction towards ethyl acetate and diethyl ether for carbocation (an ion with a positively-charged carbon atom) formation may be the cause of its elevation. The results are in line with Termentzi et al., 2008. ${ }^{[28]}$ and Salas et al., 2004. ${ }^{[2]}$

\section{Free radical inhibition activities}

Nitric oxide $(\mathrm{NO})$ is an important chemical mediator which involves in the regulation of various biochemical and physiological processes. Excess concentration of $\mathrm{NO}$ is associated with several diseases. ${ }^{[30]}$ Oxygen reacts with excess amount of nitric oxide to generate nitrite and peroxynitrite anions, which act as free radicals. ${ }^{[31]}$ In this experiment, fraction containing diethyl ether and ethyl acetate showed strong scavenging and preventive capacity against NO because of the presence of higher amount of polyphenolic compounds in those fractions. ${ }^{[32,33]}$

In case of inhibition of hydroxyl radicals, fractions containing diethyl ether and ethyl acetate showed maximum activity, may be because of their higher ability to bind iron ion and potential for direct scavenging activity on $\mathrm{OH}^{-}$, which revealed the same results as Verma et al., 2010. ${ }^{[34]}$ 


\section{Antioxidant profiling of Canna edulis Ker Gawler}

In our study in vitro hepatocyte protective activity was induced in goat liver by using $\mathrm{FeSO}_{4}$ and ascorbic acid and it was observed that generation of lipid peroxides were prevented by bioactive fractions of Canna rhizome extract. Maximum inhibition in Fr-F i.e. 67.89\% is same as the results obtained by Kang et al., 2011. ${ }^{[35]}$ Lowest antilipid peroxidation activity was observed in $\mathrm{Fr}$-A because of lowest level of polyphenolic compounds among the bioactive fraction. ${ }^{[36]}$ Thus among the bioactive solvent fractions of Canna rhizome lipid peroxidase activity was lower in the less polar chloroform fraction and higher in more polar ethyl acetate fraction.

\section{Compound detection through TLC}

We analysed the distribution of polyphenols in different bioactive fractions. It was found that phenolic compounds were distributed from less polar to more polar solvent i.e. chloroform to ethyl acetate fraction where as mixture of flavonoid glycoside or probably triterpene glycoside related compounds were restricted to Fr-E and Fr-F as these bioactive fractions showed their sensitivity against NP/ PEG. ${ }^{[22]}$ Therefore, it may be concluded that the polyphenols present in Canna rhizome may be responsible for their antiradical scavenging activity. Phenols and flavonoids have already been reported to act as potent antioxidant in Alpinia nutants, ${ }^{[37]}$ Citrus sinensis ${ }^{[38]}$ etc.

\section{CONCLUSION}

We undertook the present study with an aim to make a profile of antioxidant activity of an important edible ornamental plant of sub Himalayan West Bengal and Sikkim which is also used widely as medicinal plants among tribal. We also had an aim to establish this important plant as a medicinal one, scientifically. In conclusion, the result of the present work indicated that, among the different solvent fractions derived from Canna edulis rhizome, the more polar fractions like Fr-D, Fr-E and Fr-F possessed highest antioxidant activity and free radical scavenging activity. It was analysed that high scavenging activity of Canna rhizome may be due to the presence of some polyphenolic compounds like phenols, flavonoids, proanthocyanides, glycosides etc. This result also indicated that the antioxidant rich fractions of Canna may probably be used in preventing the oxidative deterioration of food. The present findings appear useful in leading to further experiments on the isolation, identification, characterization and structural elucidation of the active constituents that are responsible for relatively high antioxidant activities.

\section{ACKNOWLEDGEMENT}

We are thankful to the Department of Biotechnology, Government of India for providing financial support to carry out our research.

\section{REFERENCES}

1. Halliwell B, Gutteridge JMC. Free radicals in biology and medicine. $3^{\text {rd }}$ ed. London: Clarendon Press, Oxford; 1989.

2. Yu BP. Cellular defences against damage from reactive oxygen species. Physiol rev. 1994; 74:139-162.

3. Campbell IC, Abdulla EM. Strategic approaches to in vitro neurotoxicology in Approaches \& Methods: Neurotoxicology. London: Academic Press; 1995.

4. Larson RA. The antioxidants of higher plants. Phytochemistry. 1988; 27:969-973.

5. Middha SK, Mittal Y, Talembedu U, Kumar D, Srinivasan R, Vashisth L, et al. Phyto-mellitus: A phyto-chemical database for diabetes. Bioinformation. 2009; 4(2):78-79.

6. Pratt D E. Natural antioxidants from plant material. In: Huang M, Ho C, Lee C, editors. Phenolic compounds in food and their effects on health II: Antioxidants and Cancer prevention (ACS Symposium Series 507). Washington DC: American Chemical Society; 1992. pp. 54-71.

7. Tanaka N. The utilization of edible Canna plants in southeastern Asia and southern China. Econ Bot. 2004; 58(1):112-114.

8. Sekar S, Mariappan S. Usage of traditional fermented products by Indian rural folks and IPR. Indian J Tradit know. 2007; 6(1):111-120.

9. Choudhury MD, Bawari M, Singha LS. Some Antipyretic Ethno-medicinal plant of Manipuri community of Barak Valley, Assam, India. Ethnobotanical leaflets. 2010; 14(1):21-28.

10. Mishra T, Goyal AK, Mondal P, Sen A. Free radical scavenging activity of ornamental and edible cultivars of Canna found in Eastern India. NBU J Pl Sc. 2011; 5(1):41-45.

11. Atrooz OM. The incorporation effects of methanolic extracts of some plant seeds on the stability of phosphatidylcholine liposomes. Pak J Biol Sci. 2007; 10(10):1643-1648.

12. Vankar PS, Srivastava J. Comparative Study of Total Phenol, Flavonoid Contents and Antioxidant Activity in Canna indica and Hibiscus rosa sinensis: Prospective Natural Food Dyes. Int J Food Eng. 2008; 4(3):1-17.

13. Joshi YM, Kadam VJ, Kaldhone PR. In vitro antioxidant activity of methanolic extract of aerial parts of Canna indica L.. JPR. 2009; 2(11):1712-1715.

14. Ravishankara MN, Srivastava L, Padh H, Rajani M. Evaluation of antioxidant properties of root bark of Hemidesmus indicus. Phytomedicine. 2002; 9:153-157.

15. Vanni T, Rajani M, Sarkar S, Sishoo CJ. Antioxidant properties of the ayurvedic formulations of Triphala and it's constituents. Int J Pharmacol. 1997; 35(5):313-317.

16. Bhattacharya M, Mandal P, Sen A. In vitro detection of antioxidants in different solvent fractions of Ginger (ZINGIBER OFFICINALE ROSC.). Indian J Plant Physi. 2009; 14(1):23-27.

17. Kumaran A, Karunakaran RJ. In vitro antioxidant activities of methanol extracts of Phyllantus species from India. Lebensm-Wiss technol. 2007; 40:344-352.

18. Sun JS, Tsuang YW, Chen JJ, Huang WC, Hang YS, Lu FJ. An ultra-weak chemiluminescence study on oxidative stress in rabbits following acute thermal injury. Burns. 1998; 24:225-231.

19. Marcocci L, Maguire JJ, Droy-Lefaix MT, Packer L. The nitric oxide scavenging properties of Ginkgo biloba extract EGb 761. Biochem Biophys Res Commun. 1994; 201:748-755.

20. Sreejayan N, Rao MNA. Nitric oxide scavenging by Curcuminoids. J Pharm Pharmacol. 1997; 49(1):105-107.

21. Kunchandy E, Rao MNA. Oxygen radical scavenging activity of Curcuminoids. Int J Pharm. 1990; 58:237-240.

22. Kumar VP, Sashidhara S, Kumar MN, Shidhara BY. Effect of Luffa achinata on lipid peroxidation and free radical scavenging activity. J Pharm Pharmacol. 2000; 52:891-894. 


\section{Antioxidant profiling of Canna edulis Ker Gawler}

23. Wagner H, Bladt S. Plant drug analysis: A Thin Layer Chromatography Atlas. Berlin: Springer-Verlag; 1996.

24. Lloyd RV, Hanna PM, Mason RP. The origin of the hydroxyl radical oxygen in the Fenton reaction. Free Radic Biol Med. 1997; 22:885-888.

25. Kaneko T, Tahara S, Matsu M. Retarding effect of dietary restriction on the accumulation of 8-hydroxy-2-deoxyguanosine in organs of fischer 344 rats during aging. J Free Radic Biol Med. 1997; 23:76-81.

26. Coyle JT, Puttfarcken P. Oxidative stress, glutamate and neurodegenerative diseases. Science. 1993; 219:1184-1190.

27. Mishra T, Goyal AK, Middha SK, Sen A. Antioxidative properties of Canna edulis Ker Gawler. IJNPR. 2011; 2(3):315-321.

28. Termentzi A, Alexiou P, Demopoulos VJ, Kokkalou E. The aldose reductase inhibitory capacity of Sorbus domestica fruit extract depends on their phenolic content and may be useful for the control of diabetic complications. Pharmazie. 2008; 63:693-696.

29. Salas E, Atanasova V, Poncet-Legrand C, Meudec E, Mazauric JP, Cheynier V. Demonstration of the occurrence of flavonol anthocyanin adducts in wine and in model solutions. Analytica Chimica Acta. 2004; 513:325-332.

30. Mondal SK, Chakraborty G, Gupta M, Mazumdar UK. In vitro antioxidant activity of Diospyros malabarica Kostel bark. Indian J Exp Biol. 2006; 44:39-44.

31. Cotran RS, Kumar V, Collins T. Robbin's pathological basis of diseases. $6^{\text {th }}$ ed. Noida, India: Thomson Press (1) Ltd; 1999.
32. Bahramikia S, Yazdanparast R. Antioxidant and free radical activities of different fractions of Anetbum graveolens leaves using in vitro models. Pharmacologyonline. 2008; 2:219-233.

33. Singh BN, Singh BR, Singh RL, Prakash D, Singh DP, Sharma BK, et al. Polyphenolics from various extracts/fractions of red onion (Allium cepa) peel with potent antioxidant and antimutagenic activities. Food Chem Toxicol. 2009; 47:1161-1167.

34. Verma AR, Vijayakumar M, Rao CV, Mathela CS. In vitro and in vivo antioxidant and DNA damage protective activity of green fruit of Ficus glomerata. Food Chem Toxicol. 2010; 48(2):704-709.

35. Kang S, Kim D, Lee BH, Kim MR, Chiang M, Hong J. Antioxidant Properties and Cytotoxic Effects of Fractions from Glasswort (Salicornia herbacea) Seed Extracts on Human Intestinal cells. Food Sci Biotechnol. 2011; 20(1):115-122.

36. Kviecinski MR, Felipe KB, Correia JFG, Ferreira EA, Rossi MH, Gatti FM, et al. Brazilian Bidens pilosa Linn yields fraction containing quarcetin derived flavonoid with free radical scavenger activity and hepatoprotective effects. Libyan J Med. 2011; 6:5651 - DOI: 10.3402/ ljm. v6i0.5651.

37. Habsah M, Nordin LH, Ali AM, Sukari MA, Hin YY, Kikuzaki H, et al. The antioxidative components from Alpinia nutans. Pharmaceutical Biol. 2003; 41:7-9.

38. Anagnostopoulou MA, Kefalas P, Papageorgiou VP, Assimopoulou AN, Boskou D. Radical scavenging activity of various extracts and fractions of sweet orange peel (Citrus sinensis). Food chem. 2006; 94:19-25. 